\title{
2. BACKGROUND AND OBJECTIVES OF THE NEW JERSEY TRANSECT: CONTINENTAL SLOPE AND UPPER RISE ${ }^{1}$
}

\author{
C. Wylie Poag, U.S. Geological Survey \\ and \\ A. B. Watts, Lamont-Doherty Geological Observatory ${ }^{2}$
}

\section{INTRODUCTION}

Baltimore Canyon Trough, the most intensely studied offshore sedimentary basin of the U.S. Atlantic margin, encompasses the coastal plain, continental shelf, and continental slope of New Jersey, Delaware, Maryland, and (in part) Virginia (Fig. 1). Outcrop and subsurface investigations of the coastal plain have been carried out since the early 1800 s. Offshore studies began in the 1950 s (e.g., Drake et al., 1959) and have intensified since 1973 as a result of renewed interest in offshore petroleum leasing. Forty-one offshore boreholes and numerous seafloor samples now provide a geologic basis for interpreting thousands of line-kilometers of seismic reflection profiles. Summaries of the structural and stratigraphic framework and depositional history have been published by a number of authors, including recent studies by Klitgord and Grow (1980), Schlee (1981), and Poag (1980, 1985). On the basis of the extensive published record of these geological and geophysical investigations, the New Jersey margin was chosen as the most suitable location for constructing the first marginwide stratigraphic transect. As envisioned, the transect would extend from the outcrop belt in central New Jersey to a location $700 \mathrm{~km}$ distant on the lower continental rise. Initial Deep Sea Drilling Project (DSDP) core holes on the slope and upper rise would emphasize the Cenozoic and Upper Cretaceous sections, as dictated by the limitations of openhole drilling. However, future coring could be expected to provide comparable data from more deeply buried Mesozoic deposits and basement rocks.

Leg 93 began the current phase of drilling on the New Jersey Transect by placing two shallow core sites (maximum penetration $816.7 \mathrm{~m}$ ) on the upper continental rise (Sites 604, 605; Fig. 1). In addition, Leg 93 established the extreme oceanward end of the transect at Site 603 on the lower rise east of Cape Hatteras, where a penetration of $1585.2 \mathrm{~m}$ nearly reached basement and recovered rocks as old as Valanginian (Early Cretaceous). Leg 95 was principally intended to provide a crucial link between shelf and lower rise sites.

The U.S. Geological Survey and the Bundesanstalt für Geowissenschaften und Rohstoffe (BGR) have collected

\footnotetext{
${ }^{1}$ Poag, C. W., Watts, A. B., et al., Init. Repts. DSDP, 95: Washington (U.S. Govt. Printing Office).

2 Addresses: (Poag) U.S. Geological Survey, Woods Hole, MA 02543; (Watts) LamontDoherty Geological Observatory of Columbia University, Palisades, NY 10964.
}

more than 6,000 line-km of multichannel and 15,000 line-km of single-channel, high-resolution seismic reflection profiles in the Baltimore Canyon Trough region (Figs. 1, 2; Robb and Kirby, 1980; Schlee, 1981, Hampson and Robb, in press). A large number of lines have also been collected by Lamont-Doherty Geological Observatory, Woods Hole Oceanographic Institution, and other organizations. These lines provide a dense network of seismostratigraphic sections along the New Jersey slope and rise.

Calibration of these profiles is provided by a series of boreholes. Sixteen wells in New Jersey (Olsson et al., 1980), four wells on the shelf and upper slope (Poag, $1980,1985)$, and eight shallow holes on the middle slope and shelf (Poag, 1985) provide the principal geologic control (Fig. 1). Thirty-three additional commercial wells on the outer shelf have been released to the public domain (Giardano et al., 1984; Libby-French, 1984) but at this writing have not been thoroughly analyzed.

The standard reference section for the Baltimore Canyon Trough is U.S.G.S. seismic reflection profile Line 25 (Grow, 1980), which crosses the depocenter in a southeastward direction, beginning $20 \mathrm{~km}$ off Atlantic City, New Jersey, and passing $10 \mathrm{~km}$ south of the COST B-3 well (Fig. 1). Poag (1985) has integrated sesimic and borehole data in a detailed description and analysis of this section. The principal DSDP sites proposed for the New Jersey margin have been located on or near Line 25 in order to maximize the accuracy of seismic correlations at all present and future sites along the transect.

\section{STRATIGRAPHIC FRAMEWORK AND DEPOSITIONAL HISTORY OF THE NEW JERSEY MARGIN}

The offshore part of the Baltimore Canyon Trough occupies approximately $200,000 \mathrm{~km}^{2}$ of the continental shelf and slope between Cape Hatteras, North Carolina and Long Island, New York (Figs. 1 and 3). Its depocenter lies seaward of Atlantic City, New Jersey, where more than $18 \mathrm{~km}$ of sedimentary fill appear to be present (Schlee, 1981; Fig. 3). The bulk of these strata are of Jurassic age (more than $11 \mathrm{~km}$ maximum thickness; Fig. 4). The Cretaceous and Cenozoic sections are each approximately $2 \mathrm{~km}$ thick at maximum. As the initial holes of the New Jersey Transect were designed to penetrate no deeper than the upper Campanian strata, only the Maestrichtian and younger stratigraphy is summarized here (see Poag, 1985 for a more detailed discussion). 


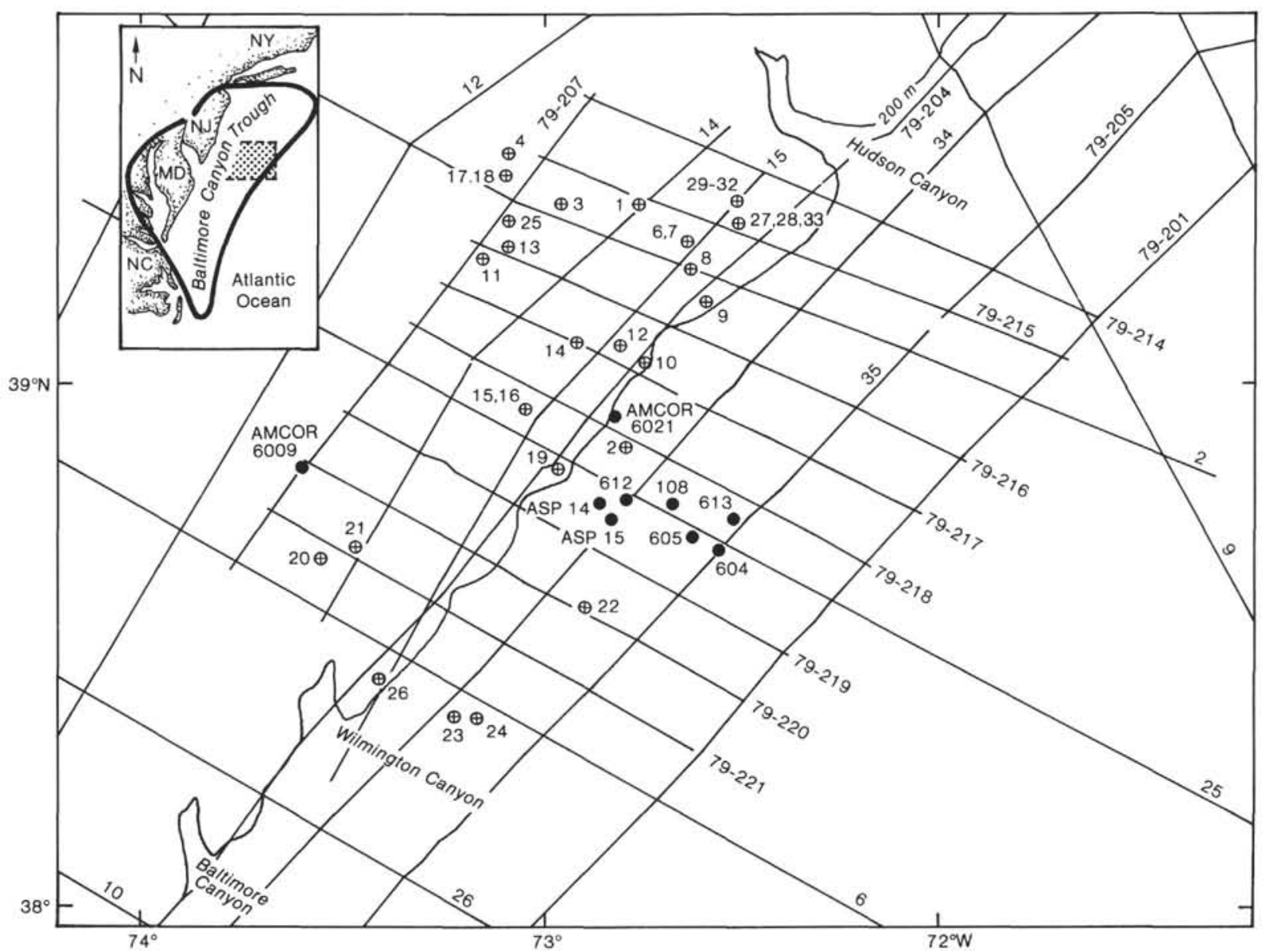

Figure 1. Location of principal offshore borings and multichannel seismic reflection profiles on the central New Jersey Continental Slope and Rise. Solid dots = boreholes; AMCOR = Atlantic Margin Coring Project (Hathaway et al., 1979). ASP = Atlantic Slope Project (Poag, 1978). The 200-m bathymetric contour is the approximate shelf edge. Numbered circles with crosses are commercial well locations (No. 1 is COST B-2; No. 2 is COST B-3; from Poag and Valentine, in press.)

\section{Maestrichtian Strata}

Maestrichtian sediments have been identified in control wells and can be widely traced on seismic reflection profiles across the New Jersey margin. From a maximum thickness of $200 \mathrm{~m}$ beneath the outer shelf, Maestrichtian rocks thin to about $24 \mathrm{~m}$ beneath the upper slope near the B-3 well and to $6 \mathrm{~m}$ at the present shoreline (Figs. 5 and 6). The Maestrichtian section thickens again beneath the upper continental rise; Hole 605 penetrated $56.5 \mathrm{~m}$ of Maestrichtian sediments and was terminated at that point without reaching the Campanian section (Figs. 5, 6). However, the entire section has been thinned by erosion of regional extent that removed latest Cretaceous deposits. Maestrichtian lithofacies range from gray, calcareous, glauconitic clay at the shoreline to dark brown gray, calcareous, silty mudstone beneath the upper slope. On the upper rise, Site 605 encountered olive gray, clay-rich, foraminifer-nannofossil limestone. Maestrichtian paleoenvironments range from inner sublittoral to upper bathyal. Although upper Maestrichtian strata have not been indentified on the shelf and slope, they are present along with a lower Paleocene section at Site 605 on the upper rise.

\section{Paleocene Strata}

The late Paleocene ushered into the Baltimore Canyon Trough a dominantly carbonate depositional regime that lasted through the late Eocene. From a maximum thickness of $250 \mathrm{~m}$ on the outer shelf (Shell 272-1 well; Poag, 1985) the upper Paleocene section thins to $47 \mathrm{~m}$ at the shoreline and to less than $50 \mathrm{~m}$ beneath the middle slope (Figs. 5 and 6). Paleocene strata thicken again to $196 \mathrm{~m}$ beneath the upper rise at DSDP Site 605. The Paleocene lithofacies range from glauconitic sands of inner sublittoral origin at the outcrop, to white, chalky, bathyal limestone beneath the slope, becoming dark greenish gray, clayey to silty, partly glauconitic, nannofossil limestones beneath the upper rise.

\section{Eocene Strata}

Carbonate deposition continued during the Eocene while a major transgression moved outer sublittoral environments landward as far as the present shoreline. As much as $650 \mathrm{~m}$ of Eocene strata accumulated beneath the inner shelf. Beneath the present shoreline (U.S.G.S. Island Beach No. 1 well; Poag, 1985), the section consists of $110 \mathrm{~m}$ of light to dark greenish gray, calcareous, 


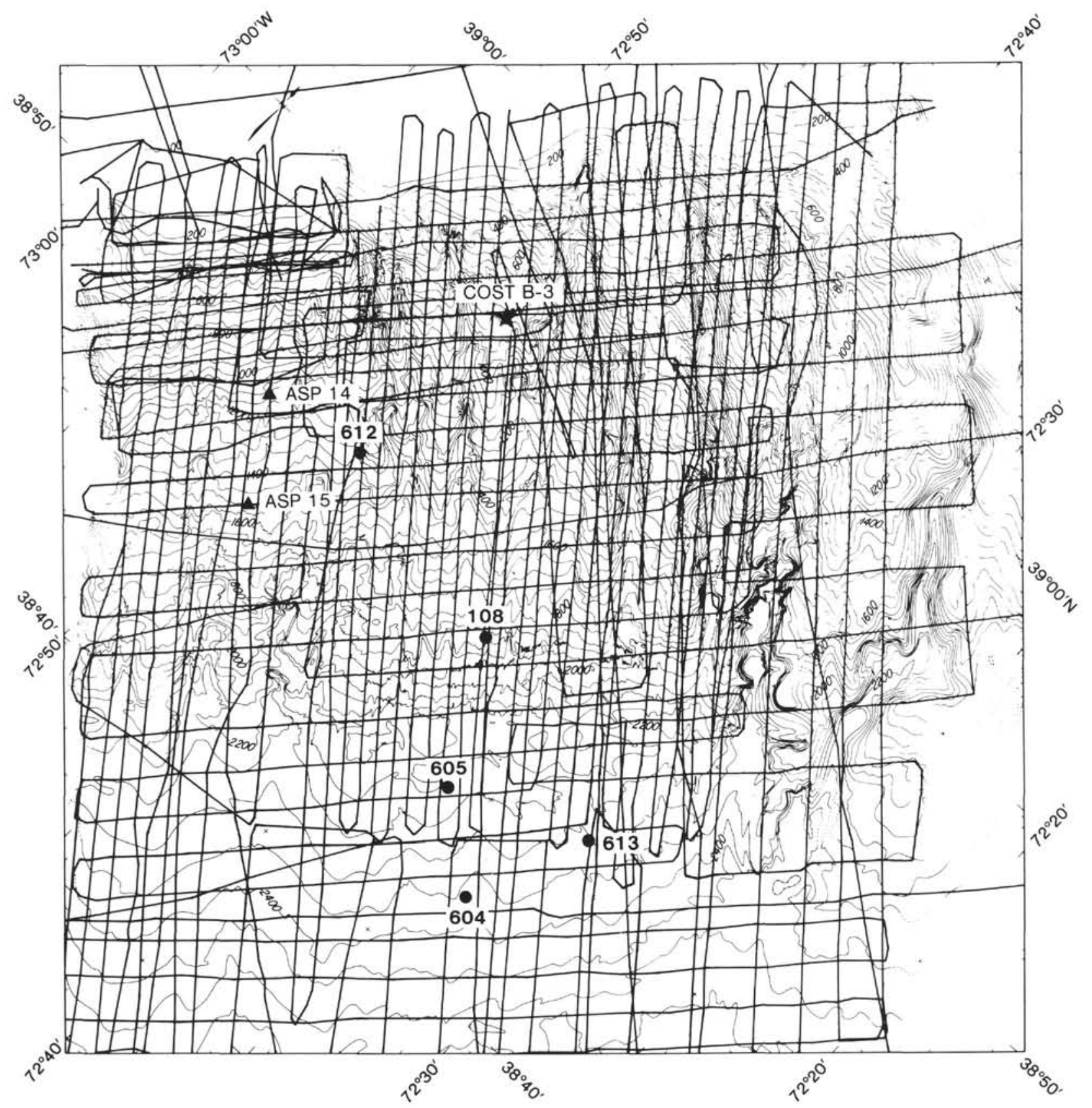

Figure 2. Grid of single-channel high-resolution seismic reflection lines on the New Jersey Slope in the vicinity of the New Jersey Transect (from Hampson and Robb, 1984).

glauconitic clay containing fragmental limestones (Manasquan Formation). Beneath the upper slope (COST B3 well; Poag, 1985), $320 \mathrm{~m}$ of white to gray calcareous claystone and chalk have been documented (Figs. 5 and 6). Beneath the upper rise, a nearly equal thickness is maintained (365.8 $\mathrm{m}$ at Site 605$)$, and strata are composed of greenish gray, partly biosiliceous, nannofossil limestone and chalk. Upper Eocene deposits are incompletely represented or entirely missing throughout the study area because of major erosion during the late Eocene to early Oligocene interval. Resistant middle Eocene carbonates are exposed in a wide outcrop belt along the lower continental slope (Fig. 7; Robb et al., 1981 a,b, 1983; Hampson and Robb, 1984), where cores reveal white to light gray, clayey, biogenic oozes and nannofossil limestones containing radiolarians (e.g., DSDP Site 108; Hollister, Ewing, et al., 1972). Lower Eocene strata are characteristically altered by silica diagenesis throughout the region (from the coastal plain to the continental rise), especially in the upper beds.

\section{Oligocene Strata}

A siliciclastic depositional regime returned to the Baltimore Canyon Trough during the Oligocene and has been maintained to the present. Early Oligocene rocks are missing over most of the shelf and upper slope, but they 


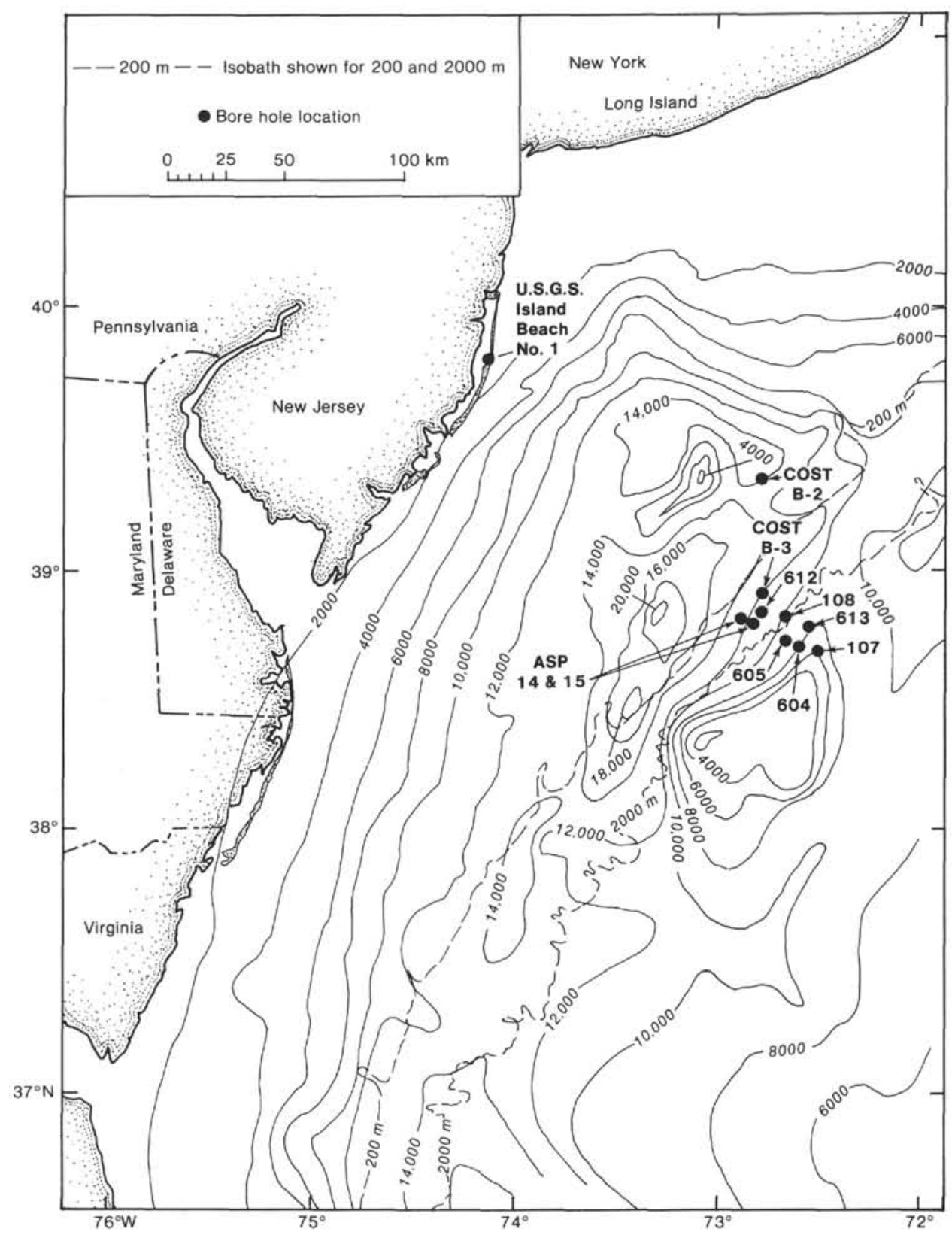

Figure 3. Isopach map of sedimentary fill in the Baltimore Canyon Trough. Location of selected boreholes shown. DSDP sites listed by number only. (After Bayer and Mattick, 1980.)

are known from an incompletely cored section at Site ASP 15 where they comprise at least $9 \mathrm{~m}$ of gray, calcareous, glauconitic marl and clay (Figs. 5 and 6; Poag, 1985).

Upper Oligocene strata, on the other hand, are widespread on the shelf and upper slope, reaching a maximum thickness of 200 to $250 \mathrm{~m}$ beneath the outer shelf (COST B-2 well; Poag, 1985). Approximately $15 \mathrm{~m}$ of Oligocene greensand is present near the shoreline (U.S.G.S. Island Beach No. 1 well; Poag, 1985) and 91 $\mathrm{m}$ of light olive gray, glauconitic calcareous clay is present beneath the upper slope (COST B-3 well; Poag, 1985). The Oligocene section thins to a feather edge and may crop out at scattered locations on the lower slope (Hampson and Robb, 1984). Its presence has not yet been confirmed within the upper rise prism.

\section{Miocene Strata}

Miocene strata constitute the thickest Cenozoic sedimentary unit in the Baltimore Canyon Trough. They consist of a series of prograding deltaic wedges that reach a maximum thickness of $1000 \mathrm{~m}$ beneath the present outer shelf (COST B-2 well; Poag, 1985). Most of the unit is of middle Miocene age and several periods of erosion have reduced its original thickness (Figs. 5 and 6). Miocene strata thin toward the coastline, where about $100 \mathrm{~m}$ of glauconitic, micaceous; shelly, medium to coarse sand contains several beds of gray lignitic clay (U.S.G.S. Island Beach No. 1 well; Poag, 1985).

On the upper slope, $364 \mathrm{~m}$ of lower, middle, and upper Miocene strata comprise chiefly glauconitic, micaceous, organic-rich, silty clays and traces of glauconitic 


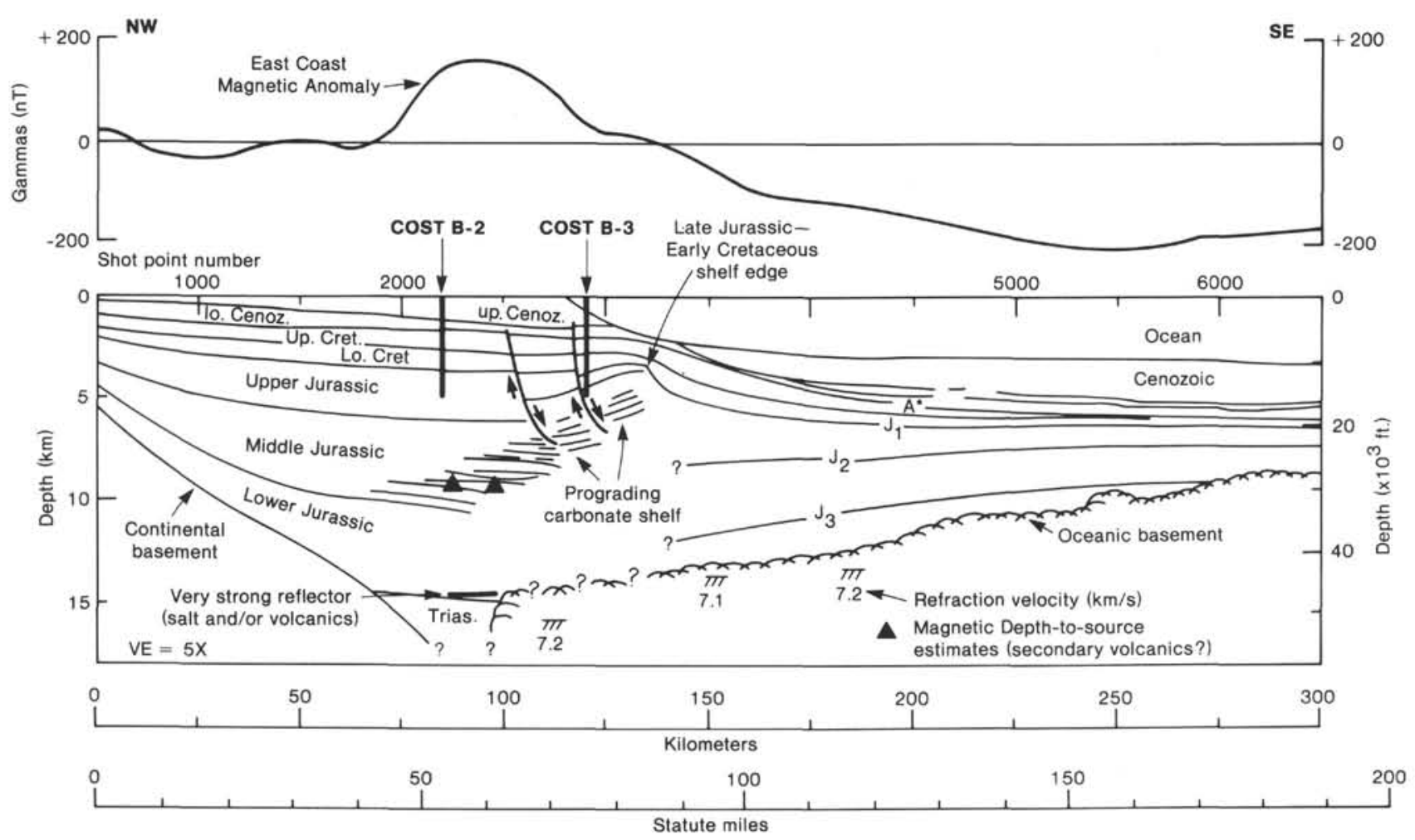

Figure 4. Schematic geologic section of the Baltimore Canyon Trough along USGS multichannel seismic reflection profile 25 . $A^{*}, \mathrm{~J}_{1}, \mathrm{~J}_{2}$, and $\mathrm{J}_{3}$ are prominent seismic reflectors. (After Grow, 1980.) COST B-2 and B-3 are boreholes.

sandstone (COST B-3 well; Poag, 1985). Farther down the slope, the Miocene section is exposed in the walls of several submarine canyons (Figs. 5 and 6; Hampson and Robb, 1984). Miocene strata are absent from the wide Eocene outcrop belt but are present as variably thick wedges of sandy, conglomeratic, channel-fill beneath the upper rise (e.g., DSDP Site 604).

The Miocene (chiefly middle Miocene) sands, silts, and clays of the shelf and upper slope are unusually enriched in biogenic silica at the expense of calcareous microfossils. Poag $(1980,1985)$ and Palmer (1983) have concluded that nutrient enrichment due to upwelling and deltaic sources created a highly productive photic zone on this margin during the Miocene.

\section{Pliocene Strata}

Pliocene rocks in the Baltimore Canyon Trough have been only tentatively identified and appear to be of limited distribution. The maximum thickness of presumed Pliocene strata on the upper slope is around $200 \mathrm{~m}$ (Figs. 5 and 6; Poag, 1985). Pliocene strata are not documented under the New Jersey coastal plain or continental shelf, but a few planktonic foraminifers and radiolarians of Pliocene age have been reported from the COST B-3 well (Poag, 1980, 1985). In contrast, well-documented Pliocene strata were encountered beneath the upper rise in Hole 604 where they comprise $76.8 \mathrm{~m}$ of greenish gray, biosiliceous clays containing glauconite-rich silty layers.

\section{Pleistocene Strata}

The surface sediments of the Baltimore Canyon Trough are part of a prism of chiefly Pleistocene quartzose sands, silts, and dark gray silty clays that thickens to more than $400 \mathrm{~m}$ near the shelf edge (Figs. 5 and 6; Poag, 1985). The Pleistocene strata thin rapidly down the slope, their distribution pattern being interrupted by a complex series of submarine canyons and associated shallower erosional channels. This erosion has produced a series of downslope-trending "fingers" of Pleistocene strata separated by the canyons, in whose walls older strata (as old as Late Cretaceous) crop out (Hampson and Robb, 1984). Pleistocene strata generally pinch out along the lower slope at the northwestern edge of the middle Eocene outcrop belt. A thin layer of Pleistocene silty clay covers large patches of near-surface Miocene and Eocene beds in the outcrop belt, and a thick wedge of Pleistocene interbedded silts and clays constitutes the younger beds of the upper rise ( $160 \mathrm{~m}$ at Site 604$)$. Pleistocene paleoenvironments range from nonmarine, paralic, and glaciomarine near the shoreward margin of the trough to bathyal on the slope and rise. A characteristic feature of the surficial bathyal Pleistocene strata is the common presence of displaced shelf-type benthic microfossils.

\section{Unconformities}

Poag, (1980, 1982a,b, 1985) and Poag and Schlee (1984) have discussed the widespread and frequent occurrence of stratigraphic gaps in the sedimentary basins of the Atlantic offshore region, including the Baltimore Canyon Trough (Fig. 8). In the boreholes, the presence of unconformities and duration of hiatuses has been documented by the absence of biostratigraphic zones. Seismic sequence analysis also reveals the presence of these unconformities crossing the boreholes and in un- 


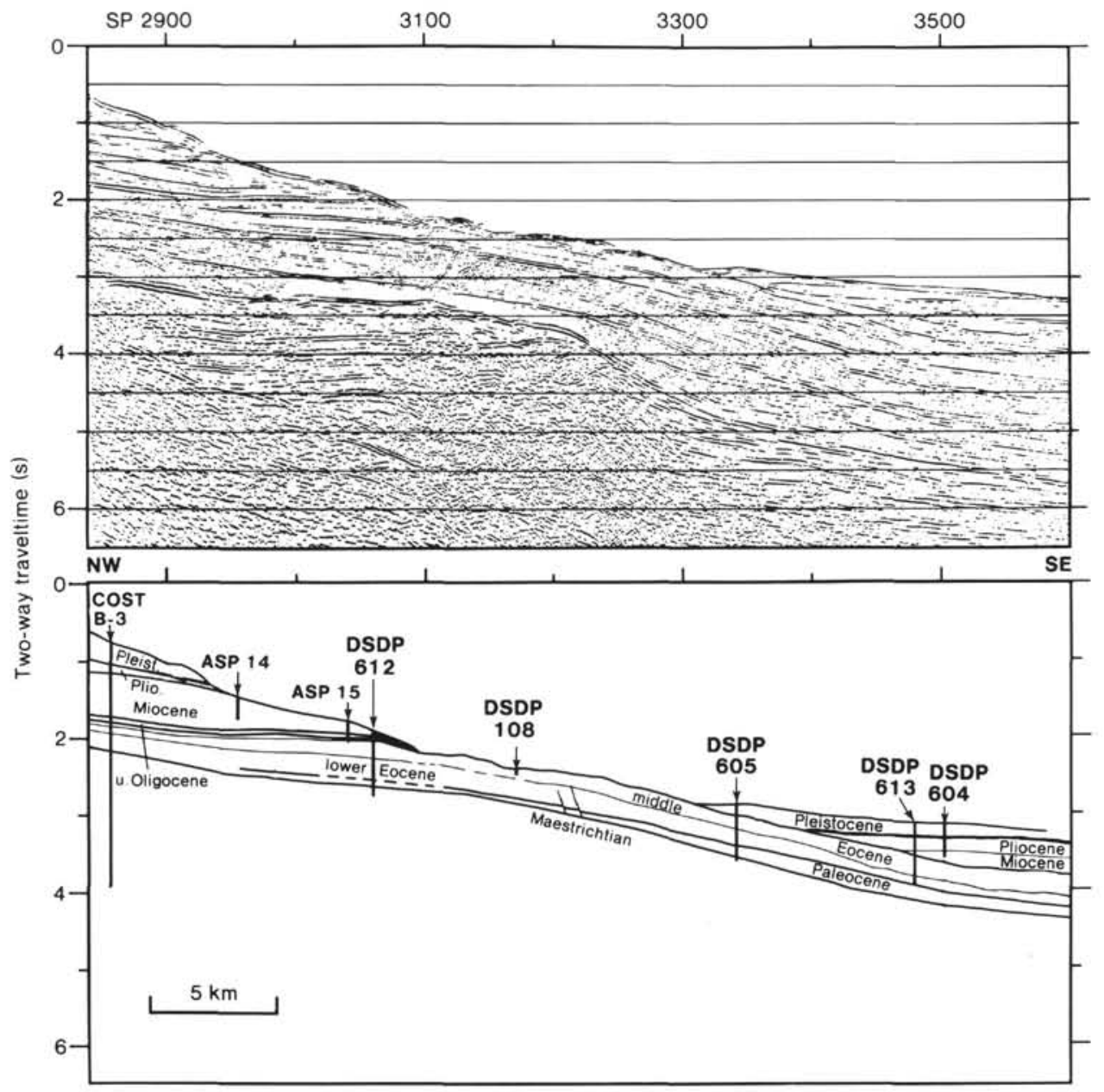

Figure 5. Seismic reflection profile and geologic interpretation along continental slope and upper rise segment of U.S.G.S. multichannel seismic reflection profile 25, southeastward of New Jersey . DSDP Site 612 is approximately on Line 25 , but other sites are projected to the line from as far away as $10 \mathrm{~km}$.

drilled sections as well. Major stage boundaries are often distinguished as distinct reflectors and can be seen to truncate underlying reflections at scattered locations along their lengths, indicating erosion. Above them, the reflections often onlap or downlap, indicating intervals of nondeposition. However, the vertical resolution of the seismic systems used is limited to around $5 \mathrm{~m}$ at depths of less than $2 \mathrm{~km}$, so that truncated or onlapping strata of lesser thickness would not show up on the profile studies (Sheriff, 1977). The boreholes show that on the shelf, where sequences are parallel bedded, unconformities sometimes appear to be conformable seismic boundaries in places where they actually represent gaps. On the continental slope, the angles between reflections are much more disparate, which makes unconformable contacts easier to recognize on seismic profiles. As a general rule, the unconformities fall into two categories:

1. Those that can be recognized from basin to basin (Blake Plateau Basin, Baltimore Canyon Trough, Georges Bank Basin) and appear to be nearly coincident with the "global" periods of erosion postulated by Vail et al. (1977); and
2. Those that have more limited extent within a single basin and do not necessarily coincide with those of the Vail scheme.

The oldest major gap expected to be encountered in the Leg 95 boreholes is the gap at the Cretaceous/Tertiary contact (Figs. 6 and 8). In the COST B-3 well, Paleocene and upper Maestrichtian (Zones UC15, UC16, UC17) strata are missing at a hiatus of about 17 to 18 m.y. (Poag, 1985). A correlative gap and an equivalent seismic unconformity can be traced widely in adjacent basins. At the COST B-3 well, the outer sublittoral paleoenvironment (Fig. 9) does not change across the unconformity, but the lithology changes from dark silty mudstone below to white biomicritic limestone above (Poag, 1985). The missing section may have been eroded by a series of subaerial and submarine processes during the lengthy hiatus.

At the COST B-2 well, however, the paleoenvironmental conditions changed markedly across the contact along with a distinctive lithic change. The youngest Maestrichtian strata present are lignitic, gypsiferous, quartzose sandstones that contain a paralic (estuarine or la- 


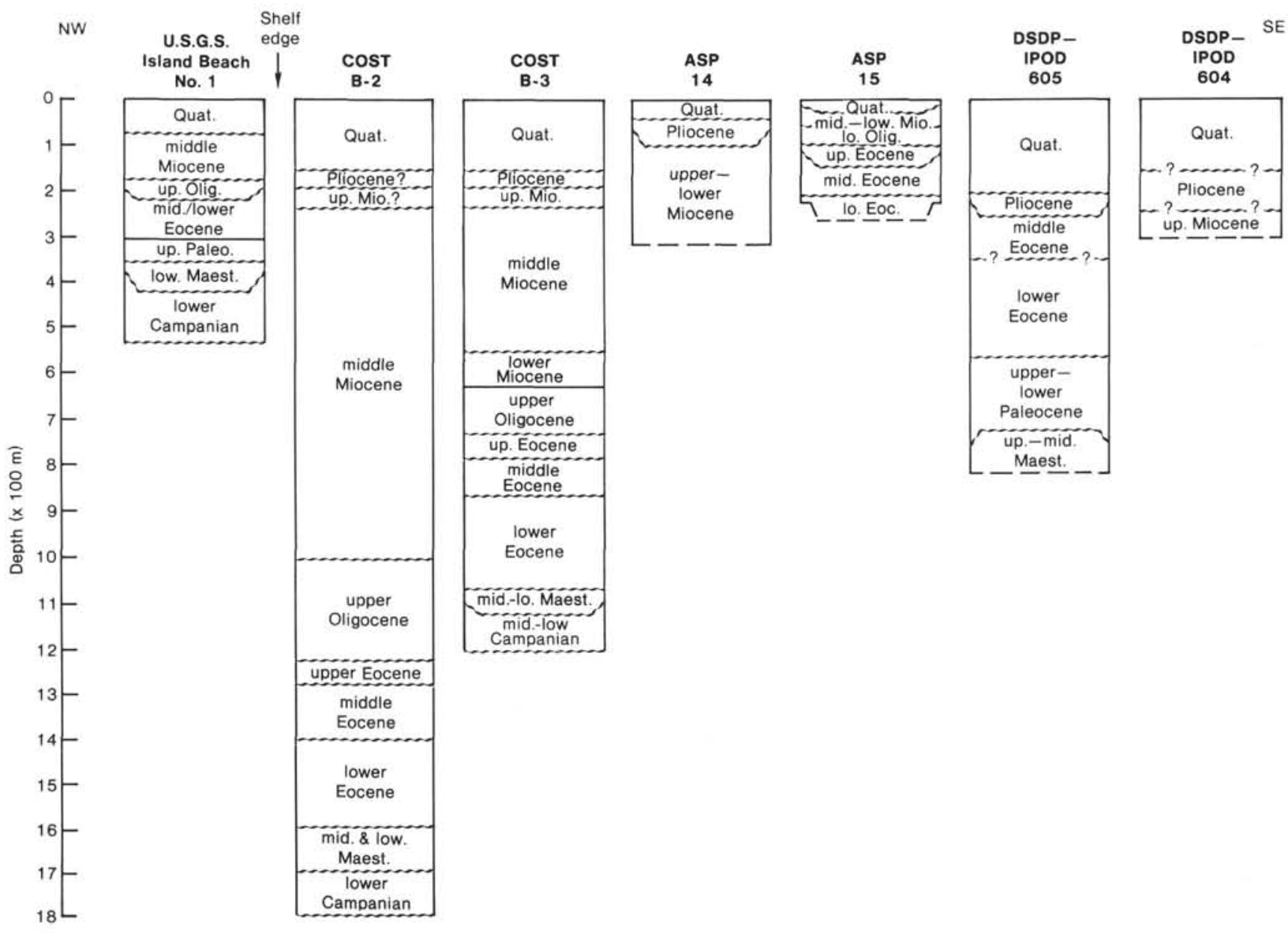

Figure 6. Stratigraphic columns for holes drilled on the New Jersey Transect prior to Leg 95. Undulating horizontal lines represent unconformities. See Figure 1 and 3 for locations of holes.

goonal) assemblage of agglutinated foraminifers. Subareial exposure is likely to have eroded part of this section prior to marine inundation in the Paleocene and consequent deposition of white chalky limestone containing outer-sublittoral foraminifers.

The next youngest well-documented unconformity separates upper Eocene beds (Zone P15) from upper Oligocene strata (Zone P21b) at about $1821 \mathrm{~m}$ (689 m BSF) in the COST B-3 well (Fig. 8). The hiatus is approximately $11 \mathrm{~m} . \mathrm{y}$. in duration. A nearly coeval unconformity is present in several other wells. This gap appears to be the result of at least two periods of intense erosion: one near the Eocene/Oligocene boundary (Olsson et al., 1980) and one near the middle of Zone P21 (Vail and Mitchum, 1979). The paleoenvironment on either side of the unconformity at the COST B-3 well is interpreted to have been lower bathyal (Fig. 9). At B-2, on the other hand, the paleoenvironment changed from upper bathyal below the unconformity to outer sublittoral above. A lithologic change from white Eocene limestone to olive gray, glauconitic, upper Oligocene clay takes place in both of the COST B-wells. The resulting acoustic impedance contrast forms a distinctive reflector that can be traced widely on seismic profiles (Carlson, 1979). One of the most significant periods of channel cutting on the continental slope has been correlated with this shelf erosion (Schlee et al., 1985; Dillon et al., 1985).

At $1356 \mathrm{~m}$ (524 m BSF) in the COST B-3 well, a stratigraphic gap is present between Zone N5(?) of the lower Miocene and Zone N9 of the middle Miocene (hiatus of 5 m.y.; Fig. 6). An even longer hiatus separates upper Oligocene from middle Miocene strata in the COST B-2 well (9 m.y. hiatus), confirming the regional distribution of this erosion. The paleoenvironment changed from lower to upper bathyal across the contact at the COST B-3 well, while at B-2, the change was from outer to inner sublittoral. Submarine currents appear to have been the erosive agents at each site. No lithologic change is associated with this unconformity at the COST B-3 well, but at B-2, a thin quartzose sandstone lies below the contact and olive gray clay lies above. This unconformity is clearly seen on seismic profiles; for example, on the shelf segment of Line 25 (Poag, 1985), where prograding middle Miocene clinoform reflections are seen to downlap Oligocene and lower Miocene reflections over long distances. This indicates that nondeposition was a major reason for this stratigraphic gap.

Several other subaerial erosion events apparently took place in the Miocene, Pliocene, and Pleistocene as indicated by repeated zones of intensely oxidized microfos- 


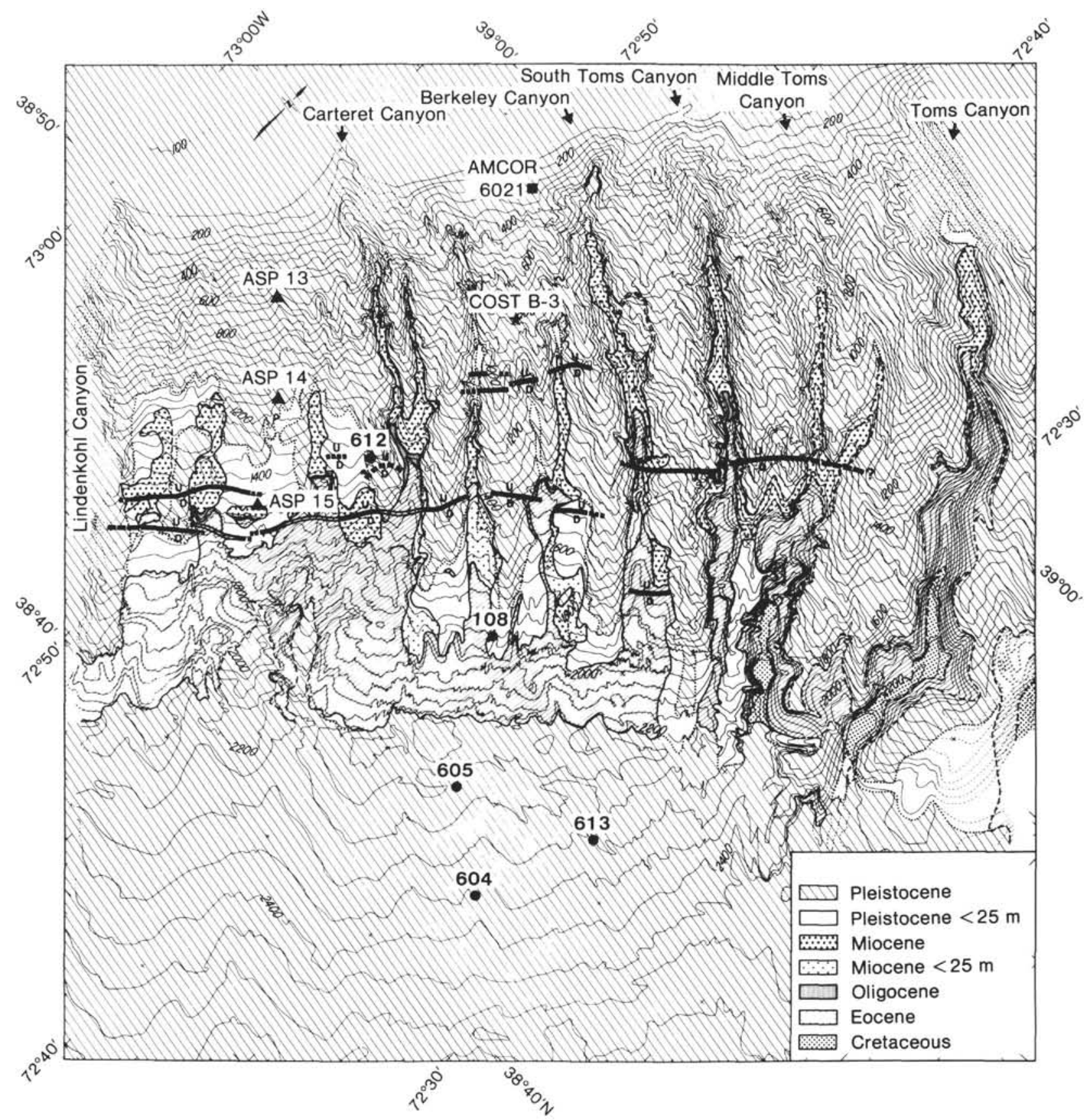

Figure 7. Geologic map of a segment of the New Jersey Continental Slope and Rise in the vicinity of the New Jersey Transect. Major normal fault systems depicted by heavy lines. (From Hampson and Robb, 1984.)

sils and sediments in the COST B-2 well and in AMCOR 6009 and 6010 cores. However, in these sections the detailed biostratigraphic zonation required to estimate the duration of hiatuses is not available. Several of these unconformities can also be seen on seismic profiles, but the relatively minor lithic differences (small impedance contrasts) within the Neogene and Quaternary strata do not produce the high-amplitude unconformable reflectors so typical of older sections.

The major unconformities cited above are generally correlative with the so-called global periods of erosion outlined by Vail et al. (1977) and Zeigler (1982), and they provide a means of identifying major depositional cycle boundaries (Figs. 6, 8, and 9).

\section{SEA-LEVEL CHANGE AND PALEOBATHYMETRIC CYCLES}

Studies of paleobathymetric cycles inferred from analyses of Atlantic offshore boreholes show good correlations with the supercycles (second order) and some thirdorder cycles of sea-level fluctuation described by Vail et al. (1977; see Poag and Hall, 1979; Poag, 1980, 1982a,b; and Poag and Schlee, 1984). Figure 9 shows a comparison of this sea-level curve with paleobathymetric curves 


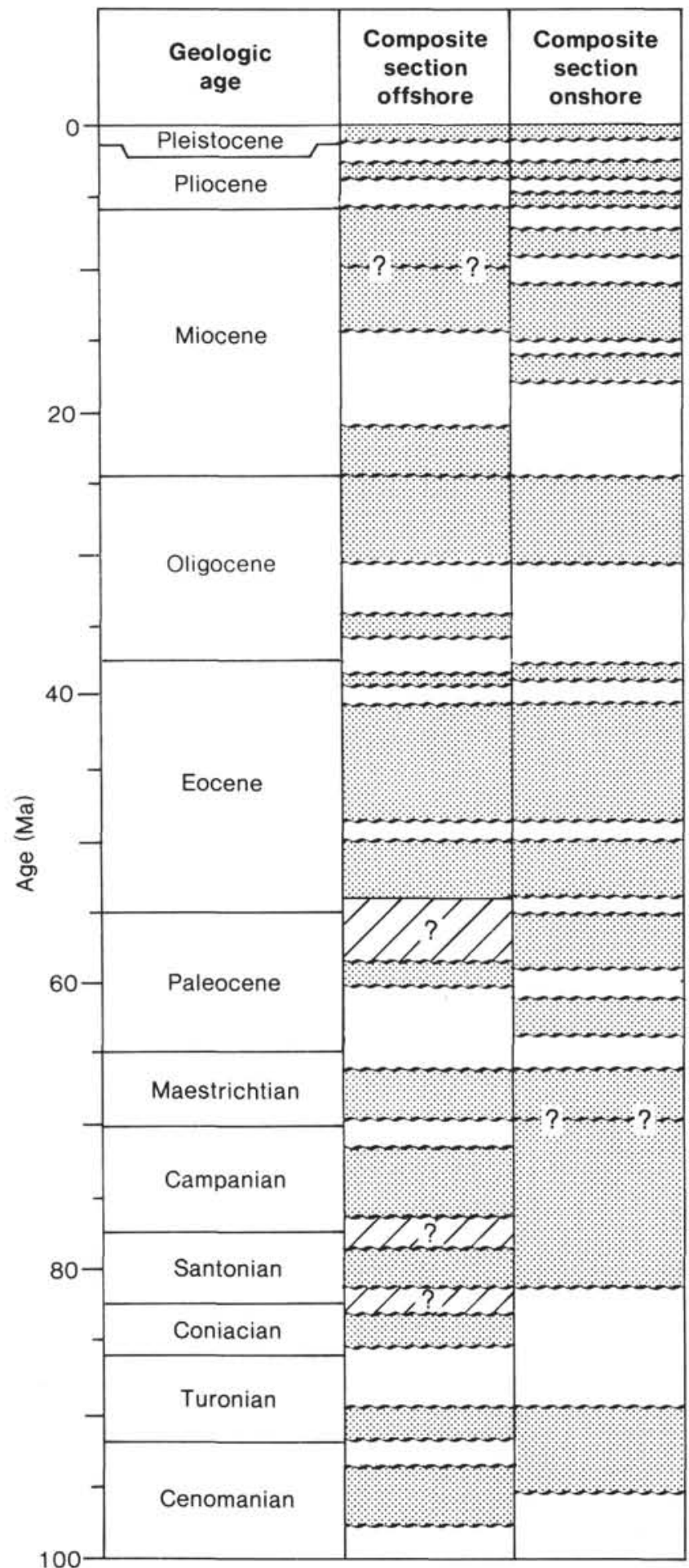

Figure 8. Composite stratigraphic columns for the offshore and onshore sections of the Baltimore Canyon Trough. Blank portions of columns represent stratigraphic gaps. (After Poag and Schlee, 1984; Ward, 1984.)

derived from the COST B-3, GE-1 (Southeast Georgia Embayment), and G-2 wells (Georges Bank Basin). In general, the correspondence of deep and shallow bathymetry with high and low sea levels, respectively, is remarkably close. Depositional cycles are broadly uniform from basin to basin for Mesozoic strata, but interbasin variability increases considerably in the Cenozoic.

The Cenozoic record in the Baltimore Canyon Trough begins with the middle of supercycle $\mathrm{T}_{\mathrm{a}}$. From this point forward, the paleodepth seems to increase somewhat in both COST B wells (with some fluctuations in B-2), although both maintained generally upper bathyal depths. Supercycle $T_{b}$ is marked by major deepening in both COST B wells, but during the middle part of supercycle $\mathrm{T}_{\mathrm{b}}$, the waters at both B-well sites shoaled.

The major sea-level drop presumed to have taken place at the $T_{b} / T_{c}$ boundary is clearly represented at the COST B-well sites, as discussed above. There is, moreover, a significant paleobathymetric change at the $T_{b} / T_{c}$ boundary in the B-2 well. A major early Miocene gap signals a low stand at the COST B sites near the middle of supercycle $T_{c}$, and the paleoenvironments above the gap at B2 were shallower than those below.

Supercycle $T_{d}$ is not well represented in any boring in the Baltimore Canyon Trough, but the upper Pliocene sediments appear to have been deposited during a transgressive phase. Pleistocene sea-level variations have not been carefully studied at this writing.

\section{SUBSIDENCE HISTORY, THERMAL EVOLUTION, AND CRUSTAL STRUCTURE}

The sediments that accumulated in the Baltimore Canyon Trough show the vertical movements (uplift and subsidence) of the crust and upper mantle that have occurred at the U.S. continental shelf and slope through time. The stratigraphic section of the shelf and slope, as revealed by exploratory drilling and multichannel seismic profiling, is the result of a number of geological processes that have interacted with each other in both space and time. Included in these processes are compaction, changes of sea level, and sedimentary loading. By analyzing sedimentary accumulation data using "backstripping" techniques (e.g., Watts and Ryan, 1976), it is possible to determine that part of the uplift and subsidence history of the shelf and slope that is not caused by loading processes and which must be due to tectonic processes. The tectonic uplift and subsidence history provides constraints on geological and geophysical models for the origin of the shelf and slope.

A number of studies have now been carried out on the subsidence history of the Baltimore Canyon Trough region using the available well and seismic data (Fig. 10; Steckler and Watts, 1978; Watts and Steckler, 1979; Royden and Keen, 1980; Sawyer et al., 1982; Heller, et al., 1982). These studies have shown that the principal factors contributing to the subsidence of the continental shelf and slope are thermal contraction and sedimentary loading. Sedimentary processes such as compaction and changes in sea level contribute to the subsidence, but their combined effects are small compared to those of thermal contraction and sedimentary loading.

It is now generally agreed that the thermal contraction inferred from well data in the Baltimore Canyon Trough arises from heating and thinning of the crust and lithosphere at the time of rifting of North America from Africa, about 170 to $180 \mathrm{Ma}$. The principal differ- 


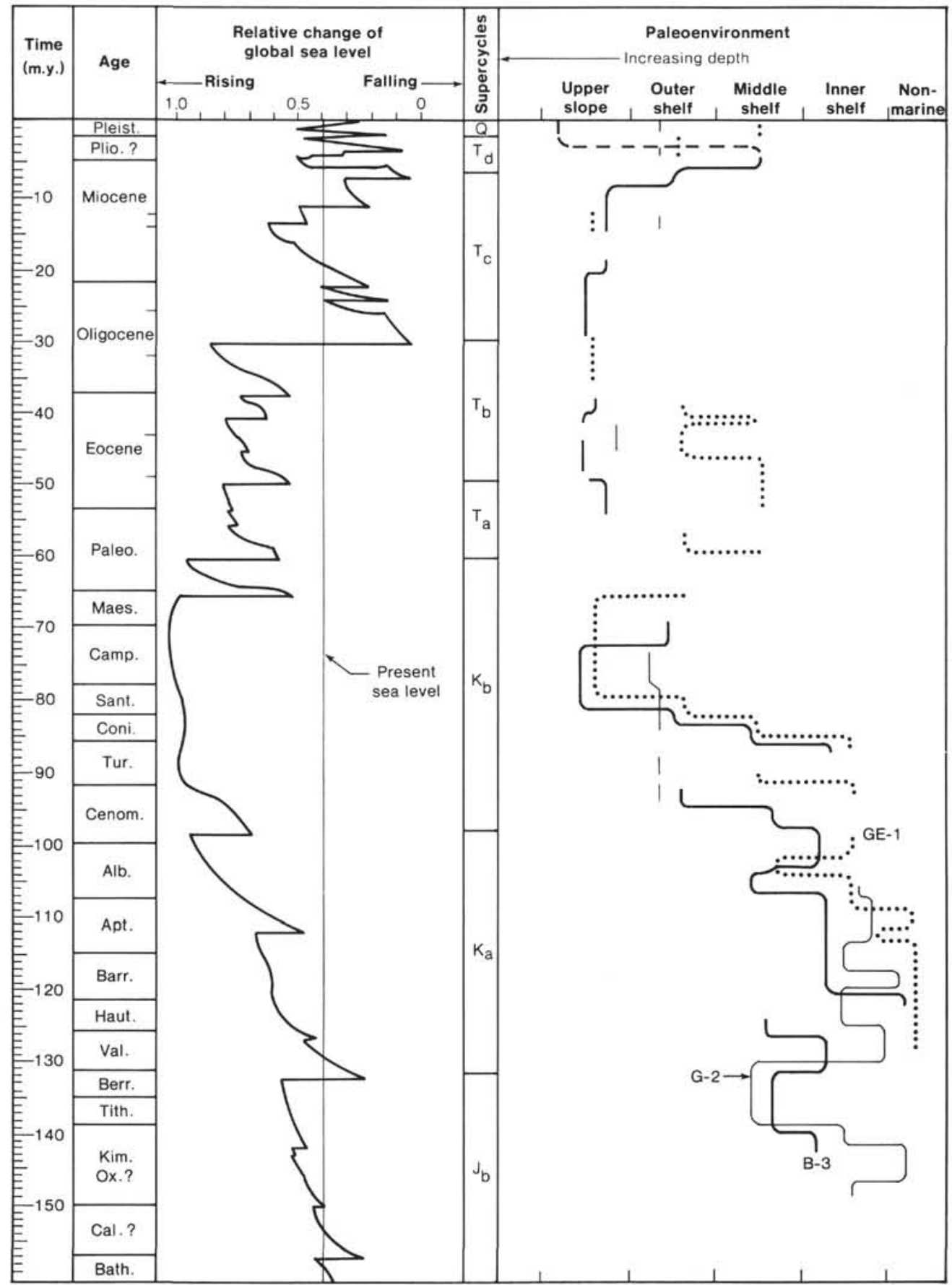

Figure 9. Generalized paleobathymetric curve for the Baltimore Canyon Trough and its adjacent Atlantic margin basins. GE-1 = COST well in the Southeast Georgia Embayment (Poag and Hall, 1979); B-3 = COST well in the Baltimore Canyon Trough (Poag, 1985); G-2 = COST well in the Georges Bank Basin (Poag, 1982b). Time scale, supercycles, and relative change of sea level from Vail et al. (1977). (Modified from Poag and Schlee, 1984.)

ences between the various models is how the heating and thinning occurs. For example, Steckler and Watts (1978) used a cooling-plate model to explain the subsidence history at the COST B-2 well. In this model, it is assumed that the crust and upper mantle in the vicinity of the well were extensively heated during rifting, after which they subsided in a manner similar to that of a mid-ocean ridge crest. Royden and Keen (1980) and Sawyer et al.,
(1982), on the other hand, used the stretching model of McKenzie (1978) to account for the subsidence. In this model, the crust and lithosphere undergo a passive extension at the time of rifting, causing crustal and lithospheric thinning and subsidence. This initial subsidence is followed by a thermal subsidence as heat is conducted to the surface and the crust and lithosphere cools. The data at the COST B-2 well are consistent with a model in 

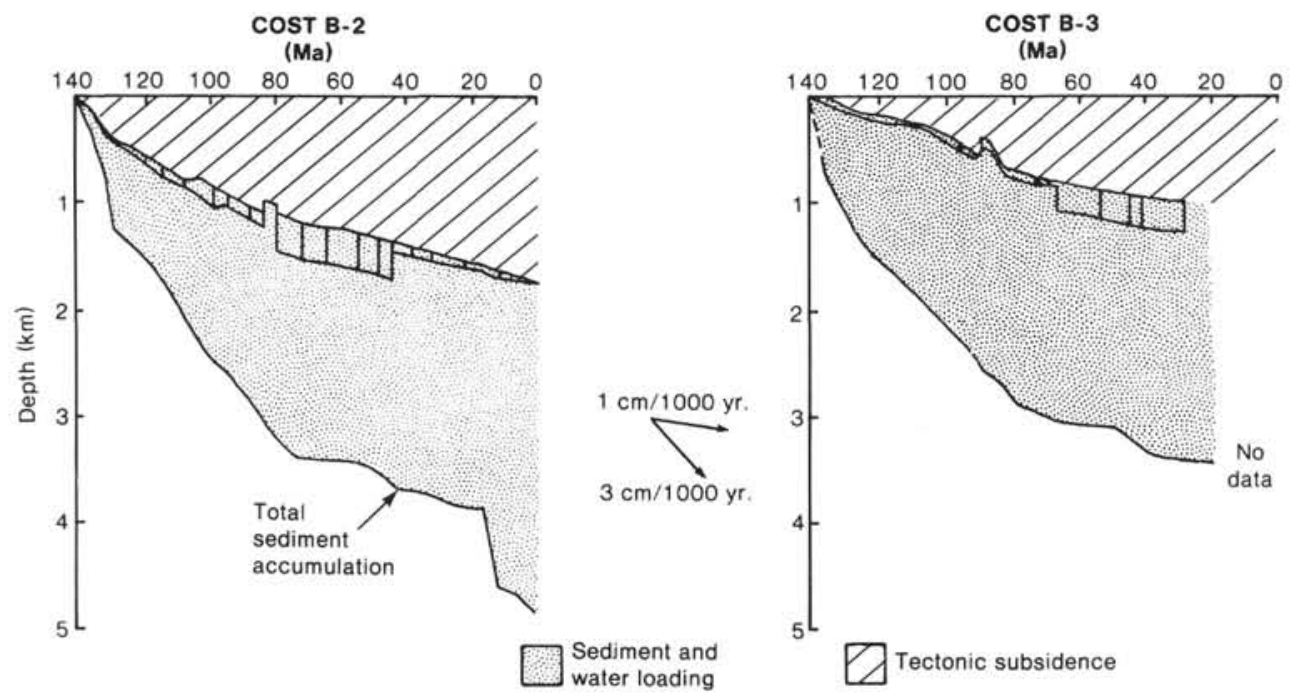

Figure 10. Tectonic subsidence and sediment accumulation at the COST B-2 and B-3 wells. The tectonic subsidence has been computed using backstripping techniques (after Watts and Steckler, 1979).

which the crust and lithosphere underlying the Baltimore Canyon Trough were uniformly extended during rifting by about a factor of three to four.

There is now good observational evidence for crustal extension during the early rifting history of several continental margins, particularly at the sediment-starved margins of the eastern Atlantic, Mediterranean Sea, and portions of the margin of eastern North America (e.g., de Charpal et al., 1978). The stretching model has generally been successfully applied to explain the subsidence history of these margins (e.g., Le Pichon and Sibuet, 1981). However, some difficulties still remain. The most important are the discrepancies between estimates of stretching based on fault geometry and deep crustal refraction data (e.g., Avedik, et al., 1982) and the relative role of passive and active heating during the evolution of those margins (e.g., Steckler and Watts, 1978).

The main contributor to the subsidence history of the Baltimore Canyon Trough following rifting is sedimentary loading. Sediments displace seawater so that they represent an excess load on the crust and lithosphere, which sag because of their added weight. By analogy with the loading of the lithosphere by oceanic volcanoes, the crust and lithosphere flex downward beneath a sedimentary load and upward in peripheral regions, because of the intrinsic strength of the lithosphere.

Several studies have now been carried out demonstrating the importance of sedimentary loading in the vicinity of the COST B-2 well (e.g., Steckler and Watts, 1978). Sedimentary loading can account for the overall shape of the basement beneath the trough, the existence of a coastal plain, and the occurrence of relative stratigraphic highs near the shelf break.

The effects of thermal contraction and sedimentary loading have been combined into thermal and mechanical models for the development of passive continental margins (e.g., Beaumont et al., 1982). These models incorporate thermal contraction following crustal and lithospheric extension at the time of rifting, and sedimentary loading of a crust and lithosphere that progressively in- crease their flexural rigidity with age. The models permit the stratigraphy of a margin to be predicted for different ages following rifting. By comparing predicted and observed cross sections of a margin, it is possible to assess the relative importance of various factors that control the stratigraphic record.

The models show that tectonics, in the form of thermal contraction and flexure, is an important factor controlling the development of a passive margin. Other factors, such as sea level, are small in terms of overall margin development, but are important modifiers of the stratigraphy, particularly in the coastal plain. Furthermore, sea level is predicted to be more important at relatively old margins than young margins, since the rate of sealevel rise or fall is more likely to exceed the rate of tectonic subsidence as a margin cools following rifting (Thorne and Watts, 1984).

A number of models have now been constructed (e.g., Thorne and Watts, 1984) that show that tectonics, in combination with long-term sea-level changes, may explain some of the features that have been identified on seismic-reflection profiles of the shelf and slope off New Jersey, such as coastal onlap and offlap. Measurements of coastal onlap and offlap were one of the means by which Vail et al. (1977) estimated sea-level changes through time. The model reveals similar patterns of onlap and offlap as derived by Vail et al. (1977), but predicts significantly fewer cycles of onlap and offlap.

An important prediction of the models is that the pattern of onlap and offlap would be expected to vary between passive margins of different ages since the role of thermal contraction and flexure varies with age following rifting. If this is the case, then the cycles in the Vail et al. (1977) global chart of relative changes of coastal onlap may be widespread, since many widely separated margins rifted at similar times, but they may not be worldwide.

The distribution and extent of seas through geological time is the result of two principal factors: global changes in sea level and tectonic movements of the crust 
and lithosphere. The occurrence of a transgressive or regressive stratigraphic sequence in a basin depends, however, on the relative heights of sea level and the seafloor (e.g., Pitman, 1978). A transgressive sequence would be expected if the rate of sea-level rise exceeded the rate of subsidence, whereas a regressive sequence would be expected if the rate of sea-level fall exceeded the rate of subsidence. Unfortunately, the rate of sea-level change is not known through geological time. As Pitman (1978) has pointed out, changes in the volume of mid-ocean ridge crests can produce average rates of sea-level of up to $1.2 \mathrm{~cm} / 1000 \mathrm{yr}$., while the waxing and waning of continental ice sheets could give rise to much larger rates. During the Tertiary, the Baltimore Canyon Trough region was subsiding at average rates of about 0.08 to 1.2 $\mathrm{cm} / 1000 \mathrm{yr}$. It seems likely, therefore, that at least some of the unconformity-bounded sequences in the trough result from the interaction of changes in the rate of sea level with the steady subsidence of the margin.

The precise dating of the unconformities during the New Jersey Transect could help to clarify the nature of the control on these stratigraphic sequences.

\section{PRINCIPAL OBJECTIVES OF LEG 95}

The principal scientific objectives of Leg 95 were to document the Cenozoic and Latest Cretaceous depositional history of the New Jersey continental slope and upper rise. Geological and geophysical analysis of continuously cored strata from these sites would allow us to

1. Establish the composition, stratigraphic framework, and depositional environments of sediments constituting the shelf/rise transition.

2. Accurately date the biostratigraphic gaps and major seismic reflectors (both conformable and unconformable) in the section.

3. Document lateral variability in bio- and lithofacies and compare the facies observed with analogues from the modern slope and rise.

4. Establish paleoenvironmental cycles, detailed biostratigraphic zonations, and stable-isotopic stratigraphy.

5. Calibrate poorly known siliceous planktonic and benthic biozones with the widely applied calcareous microfossil zonations.

6. Identify depositional sequences and evaluate their relationships with seismic sequences, sea-level changes, tectonism, oceanic current patterns, water-mass composition, and sediment provenance and accumulation rates.

7. Compare and correlate the geological and geophysical record of the slope and upper rise with that of the adjacent shelf and lower rise (especially that at Site 603) and with other passive margins such as the Goban Spur on the Irish Continental Slope (drilled on Leg 80).

8. Determine the detailed subsidence history at Site 612 by "backstripping" techniques and compare the resulting tectonic subsidence with predictions based on thermal and mechanical models for the development of passive margins.

\section{REFERENCES}

Avedik, F., Camus, A. L., Ginzburg, A., Montadert, L., Roberts, D. G., and Whitmarsh, R. B., 1982. A seismic refraction and reflexion study of the continent-ocean transition beneath the north Bis- cay margin. In Kent, P., Bott, M. H. P., McKenzie, D. P., and Williams, C. A. (Eds.), The Evolution of Sedimentary Basins: London (The Royal Society), pp. 5-26.

Bayer, K. C., and Mattick, R. E., 1980. Geologic setting. In Mattick, R. E., and Hennessy, J. L. (Eds.), Structural Framework, Stratigraphy, and Petroleum Geology of the Area of Oil and Gas Lease Sale No. 49 on the U.S. Atlantic Continental Shelf and Slope. U.S. Geological Survey Circular 812, pp. 6-8.

Beaumont, C., Keen, C. E., and Bantilier, R., 1982. A comparison of foreland and rift margin sedimentary basins. In Kent, P., Bott, M. H. P., McKenzie, D. P., and Williams, C. A. (Eds.), The Evolution of Sedimentary Basins: London (The Royal Society), pp. 295-318.

Carlson, G. R., 1979. Seismic velocity data and correlation. In Amato, R. V., and Simonis, E. K. (Eds.), Geological and Operational Summary, COST No. B-3 Well, Baltimore Canyon Trough Area, Mid-Atlantic OCS. U.S. Geological Survey Open-File Report 791159 , pp. 49-56.

de Charpal, O., Guennoc, P., Moutadeut, L., and Roberts, D. G., 1978. Rifting, crustal attenuation, and subsidence in the Bay of Biscay. Nature, 275:706-711.

Dillon, W. P., Paull, C. K., and Gilbert, L. E., 1985. History of the continental margin off Florida: The Blake Plateau basin. In Poag, C. W. (Ed.), Geological Evolution of the United States Atlantic Margin: New York (Van Nostrand Reinhold), pp. 189-215.

Drake, C. L., Ewing, M., and Sutton, G. L., 1959. Continental margins and geosynclines: the East Coast of North America north of Cape Hatteras. Phys. Chem. Earth, 3:110-198.

Giardano, A. C., Carpenter, G. B., and Amato, R. V., 1983. Oil and gas developments in Atlantic coastal plain and outer continental shelf. Am. Assoc. Pet. Geol. Bull., 67:1566-1569.

Grow, J. A., 1980. Deep structure and evolution of the Baltimore Canyon Trough in the vicinity of the COST No. B-3 well. In Scholle, P. A. (Ed.), Geological Studies of the COST No. B-3 Well, United States Mid-Atlantic Continental Slope Area. U.S. Geological Survey Circular 833, pp. 117-125.

Hampson, J. C., Jr., and Robb, J. M., 1984. Geologic Map of the Continental Slope between Lindenkohl and South Toms Canyons, Offshore New Jersey. U.S. Geological Survey Miscellaneous Investigation, $1: 50,000,1$ sheet.

Hathaway, J. C., Poag, C. W., Valentine, P. C., Miller, R. E., Schultz, D. M., Manheim, F. T., Kohout, F. A., Bothner, M. H., and Sangree, D. A., 1979. U.S. Geological Survey core drilling on the Atlantic Shelf. Science, 206:515-527.

Heller, P. L., Wentworth, C. M., and Poag, C. W., 1982. Episodic post-rift subsidence of the U.S. Atlantic continental margin. Geol. Soc. Am. Bull., 93:379-390.

Hollister, C. D., Ewing, J. I., et al., 1972. Site 108-Continental slope. In Hollister, C. D., Ewing, J. I., et al., Init. Repts. DSDP, 11: Washington (U.S. Govt. Printing Office), 357-364.

Klitgord, K. D., and Grow, J. A., 1980. Jurassic seismic stratigraphy and basement structure of western Atlantic magnetic quiet zone. Am. Assoc. Pet. Geol. Bull., 64:1658-1680.

Le Pichon, X., and Sibuet, J.-C., 1981. Passive margins; a model of formation. J. Geophys. Res. B., 86:3708-3720.

Libby-French, J., 1984. Stratigraphic framework and petroleum potential of northeastern Baltimore Canyon Trough, mid-Atlantic Outer Continental Shelf. Am. Assoc. Pet. Geol. Bull., 68:50-73.

McKenzie, D. P., 1978. Some remarks on the development of sedimentary basins. Earth Planet. Sci. Lett., 40:25-32.

Olsson, R. K., Miller, K. G., and Ungrady, T. E., 1980. Late Oligocene transgression of middle Atlantic coastal plain. Geology, 8: 549-554.

Palmer, A. A., 1983. Biostratigraphic and paleoenvironmental results from Neogene radiolarians, U.S. Mid-Atlantic Coastal Plain and continental margin. Am. Assoc. Pet. Geol. Bull., 67:528-529.

Pitman, W. C., III, 1978. Relationship between eustacy and stratigraphic sequences of passive margins. Geol. Soc. Am. Bull., 89: 1389-1403.

Poag, C. W., 1978. Stratigraphy of the Atlantic Continental Shelf and Slope of the United States. Ann. Rev. Earth Planet. Sci., 6:251-280. 1980. Foraminiferal stratigraphy, paleoenvironments, and depositional cycles in the outer Baltimore Canyon Trough. In Scholle, P. A. (Ed.), Geological Studies of the COST No. B-3 Well, United States Mid-Atlantic Continental Slope Area. U.S. Geological Survey Circular 833, pp. 44-65. 
1982a. Foraminiferal and seismic stratigraphy paleoenvironments, and depositional cycles in the Georges Bank basin. In Scholle, P. A., and Wenkam, C. R. (Eds.), Geological Studies of the COST Nos. G-1 and G-2 Wells, United States North Atlantic Outer Continental Shelf. U.S. Geological Survey Circular 861, pp. 43-91.

, 1982b. Stratigraphic reference section for Georges Bank basin depositional model for New England passive margin. Am. Assoc. Pet. Geol. Bull., 66:1021-1041.

1985. Depositional history and stratigraphic reference section for central Baltimore Canyon trough. In Poag, C. W. (Ed.), Geologic Evolution of the United States Atlantic Margin: New York (Van Nostrand Reinhold), pp. 217-264.

Poag, C. W., and Hall, R. E., 1979. Foraminiferal biostratigraphy, paleoecology, and sediment accumulation rates. In Scholle, P. A. (Ed.), Geological Studies of the COST GE-I Well, United States South Atlantic Outer Continental Shelf Area. U.S. Geological Survey Circular 800 , pp. 49-63.

Poag, C. W., and Schlee, J. S., 1984. Depositional sequences and stratigraphic gaps on submerged United States Atlantic margin. In Schlee, J. S. (Ed.), Interregional Unconformities and Petroleum Accumulation. Am. Assoc. Pet. Geol. Mem., 36:165-182.

Poag, C. W., and Valentine, P. C., in press. Mesozoic and Cenozoic stratigraphy of the United States Continental Shelf and Slope. In Sheridan, R. E., and Grow, J. A. (Eds.), The Atlantic Continental Margin. U.S. Decade of North American Geology, I-2, Geol. Soc. Am.

Robb, J. M., Hampson, J. C., Jr., Kirby, J. R., and Twichell, D. C., 1981a. Geology and Potential Hazards of the Continental Slope between Lindenkohl and South Toms Canyons, Offshore Mid-Atlantic United States. U.S. Geol. Surv. Open-File Rept. 81-600, 38.

Robb, J. M., Hampson, J. C. Jr., and Twichell, D. C., 1981b. Geomorphology and sediment stability of a segment of the U.S. Continental Slope off New Jersey. Science, 211:935-937.

Robb, J. M., and Kirby, J. R., 1980. Environmental, geologic and geophysical data kinds and sources, Baltimore Canyon trough area. U.S. Geol. Surv. Misc. Field Stud. Map, MF-1210.

Robb, J. M., Kirby, J. R., Hampson, J. C., Jr., Gibson, P. R., and Hecker, B., 1983. Furrowed outcrops of Eocene chalk on the lower continental slope offshore New Jersey. Geology, 11:182-186.

Royden, L., and Keen, C. E., 1980. Rifting process and thermal evolution of the continental margin of eastern Canada determined from subsidence curves. Earth Planet. Sci. Lett., 51:343-361.

Sawyer, D. S., Swift, B. A., Sclater, J. G., and Toksöz, M. N., 1982. Extensional model for the subsidence of the northern United States Atlantic Continental Margin. Geology, 10:134-140.
Schlee, J. S., 1981. Seismic stratigraphy of Baltimore Canyon trough. Am. Assoc. Pet. Geol. Bull., 65:26-53.

Schlee, J. S., Poag, C. W., and Hinz, K., 1985. Seismic stratigraphy of the continental slope and rise seaward of Georges Bank. In Poag, C. W. (Ed.), Geologic Evolution of the United States Atlantic Margin: New York (Van Nostrand Reinhold), pp. 265-292.

Sheriff, R. E., 1977. Limitations on resolution of seismic reflections and geologic detail derivable from them. In Payton, C. E. (Ed.), Seismic Stratigraphy-Applications to Hydrocarbon Exploration. Am. Assoc. Pet. Geol. Mem., 26:3-14.

Steckler, M. S., and Watts, A. B., 1978. Subsidence of the Atlantictype continental margin off New York. Earth Planet. Sci. Lett., 41:1-13.

Thorne, J., and Watts, A. B., 1984. Seismic reflectors and uncomformities at passive continental margins. Nature, 311:365-368.

Vail, P. R., and Mitchum, R. M., Jr., 1979. Global cycles of relative changes of sea level from seismic stratigraphy. In Watkins, J. S., Montadert, L., and Dickerson, P. W. (Eds.), Geological and Geophysical Investigations of Continental Margins. Am. Assoc. Pet. Geol. Mem., 29:469-472.

Vail, P. R., Mitchum, R. M., Jr., Todd, R. G., Widmier, J. M., Thompson, S., II, Sangree, J. B., Bubb, J. N., and Hatlelid, W. G., 1977. Seismic stratigraphy and global changes of sea level. In Payton, C. E. (Ed.), Seismic Stratigraphy-Applications to Hydrocarbon Exploration. Am. Assoc. Pet. Geol. Mem., 26:49-212.

Ward, L. G., 1984. Stratigraphy of outcropping Tertiary beds along the Pamunkey River-Central Virginia Coastal Plain. In Ward, L. G., and Kraft, K. (Eds.), Stratigraphy and Paleontology of the Outcropping Tertiary Beds in the Pamunkey River Region Central Virginia Coastal Plain. Guidebook, 1984 Field Trip, Atlantic Coastal Plain Geological Associtaton, pp. 11-77.

Watts, A. B., and Ryan, W. B. F., 1976. Flexure of the lithosphere at continental margin basins. Tectonophysics, 36:25-44.

Watts, A. B., and Steckler, M. S., 1979. Subsidence and eustacy at the continental margin of eastern North America. In Talwani, M., Hay, W. W., and Ryan, W. B. F. (Eds.), Deep Drilling Results in the Atlantic Ocean: Continental Margins and Paleoenvironments. Am. Geophys. Union., Maurice Ewing Symp., 3:273-310.

Ziegler, P. A., 1982. Geological Atlas of Western and Central Europe: The Hague (Shell International Petroleum Maatschappij).

Date of Initial Receipt: 4 February 1986

Date of Acceptance: 18 February 1986 